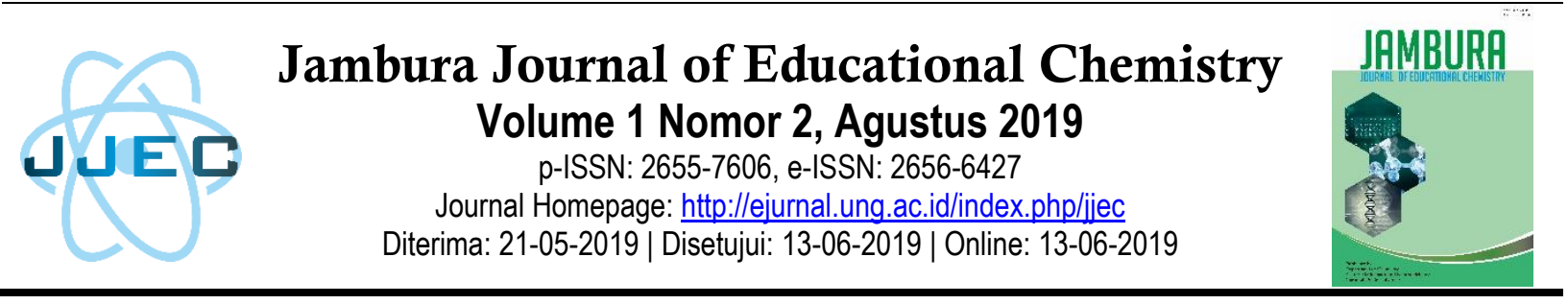

\title{
Peningkatkan Kompetensi Pedagogik Guru Kontrak Produktif Melalui Implementasi PIGP di SMKN2 Wonosari
}

\author{
Suharto Pakaya \\ Dinas Dikbudpora Provinsi Gorontalo. \\ E-mail : suhartopakaya60@gmail.com
}

\begin{abstract}
Abstrak
Salah satu kompetensi yang turut menentukan keberhasilan guru adalah kompetensi Pedagogik. Peranan kepala sekolah sebagai manajer dalam mengelola sekolah merupakan kunci keberhasilan sekolah termasuk meningkatkan kinerja guru. Karena itu, penelitian ini difokuskan pada kompetensi manajerial kepala sekolah. Penelitian ini bertujuan untuk mengetahui gambaran, mencari solusi, dalam meningkatkan kemampuan Kepala Sekolah membina Kompetensi Pedagogik guru kontrak produktif melalui implementasi Program Induksi Guru Pemula (PIGP) dengan teknik individual. Subjek Penelitian adalah kepala sekolah. Metode Penelitian berbentuk PTS melalui tahapan (Siklus). Data diperoleh dari hasil observasi, wawancara dan dokumentasi. Validasi menggunakan teknik triangulasi. Analisis dilakukan secara induktif, yaitu temuan lapangan atau fakta empiris, mempelajari, menganalisis, menafsirkan dan menarik kesimpulan dari fenomena lapangan. Hasil penelitian menunjukkan bahwa kondisi awal kepala sekolah belum melaksanakan pembimbingan terhadap guru kontrak produktif sehingga persentasi capaian 0\% (kurang). Pada Siklus I telah mencapai 72,68\% (Cukup), dan siklus II meningkat menjadi 94,33\% (Amat Baik).
\end{abstract}

Kata Kunci: Supervisi manajerial, kompotensi pedagogik, guru kontrak produktif, PIGP.

\section{PENDAHULUAN}

Kompetensi Pedagogik guru adalah kemampuan yang mutlak dimiliki oleh setiap guru, baik bagi guru PNS ataupun guru kontrak. Disadari sepenuhnya bahwa guru kontrak khususnya guru kontrak produktif di SMK kurang bersentuhan dengan pengetahuan pedagogik. Menurut UndangUndang Nomor 14 Tahun 2005 tentang Guru dan Dosen, pada pasal 10 ayat (1) menyatakan bahwa "Kompetensi guru sebagaimana dimaksud meliputi kompetensi pedagogik, kompetensi kepribadian, kompetensi sosial, dan kompetensi profesional yang diperoleh melalui pendidikan profesi"
Selanjutntya Standar kompotensi guru sebagaimana yang dituangkan dalam Peraturan Pemerintah nomor 74 tahun 2008 tentang guru dan PermenegPAN dan RB nomor 16 tahun 2009 tentang jabatan funsional guru dan angka kreditnya, telah menyinggung pula empat kompetensi guru. Berdasarkan ketentuan tentang kompetensi Guru. Salah satu kompetensi yang turut menentukan bagi keberhasilan guru adalah kompetensi Pedagogik. Adapun kompetensi Guru dimaksud adalah: 1) memahami latar belakang siswa, 2) memahami teori belajar, 3) pengembangan kurikulum, 4) aktifitas 
pengembangan pendidikan, 5) peningkatan potensi siswa, 6) komuniasi dengan siswa, serta 7) asesmen dan evaluasi. Di duga bahwa kemampuan pengetahuan guru produktif khusunya di SMKN 2 Wonosari, semata-mata hanya berkisar pada pengetahuan murni sesuai jurusan yang digelutinya di perguruan tinggi, namun karena tenaganya dibutuhkan dalam memenuhi tenaga pengajar dalam bidang - bidang tertentu terutama jurusanjurusan yang ada di SMK yang memiliki jurusan dan keahlian tertentu maka jurusan-jurusan ini direkrut untuk memenuhi jumlah guru yang sangat kurang sesuai kebutuhan pemerintah. Oleh karenanya lulusan Perguruan tinggi non kependidikan diberi peluang untuk menjadi guru tetapi tidak dibekali dengan pengetahuan akademik. Salah satu pertimbangannya adalah bahwa kompetensi pedagogik guru dapat diperoleh melalui pendidikan dan pelatihan, workshop dan atau pem langsung dari atasan yang antara lain dapat dilakukan melalui program Induksi guru Pemula. Sebagai prioritas utama dalam kompetensi tersebut adalah kompetensi pedagogik yang sangat berhubungan langsung dengan siswa. Oleh karenanya setiap guru harus memiliki kompetensi pedagogik yang maksimal. Hal ini dimaksudkan agar dalam upaya peningkatan kualitas pendidikan di Indonesia harus dilaksanakan secara professional oleh pelaku pendidikan, diantaranya adalah guru. Guru sebagai pelaksana tugas kependidikan digaris depan dituntut harus menguasai kompetensi pedagogik, baik bagi guru umum maupun kepada guru kontrak produktif. Dalam kaitan dengan tugas pokok guru diisyaratkan bahwa guru profesional adalah guru yang bukan hanya menguasai ilmu pengetahuan akan tetapi juga guru yang trampil dalam kegiatan belajar mengajar. Terutama 1) memahami Latar Belakang Siswa, 2) Memahami teori Pembelajaran, 3) Pengembangan Kurikulum, 4) Aktivitas Pengembangan Pendidikan, 5) Mengembangkan Potensi Siswa, 6) Komunikasi dengan siswa, dan 7) Penilaian dan Evaluasi.

Pengawas Sekolah, dalam konteks perubahan pendidikan adalah elemen yang dapat memberikan pencerahan yang bersifat komprehensif di lingkungan persekolahan. Kinerja pengawas sekolah memiliki kedudukan strategis dalam menciptakan situasi yang kondusif bagi pencapaian kinerja setiap elemen yang ada di sekolah terutama kepala sekolah. Akhir dari pelaksanaan kinerja pengawas, adalah terciptanya personil kepala sekolah yang memiliki kemampuan profesional, sehingga mampu melakukan perubahan menuju ke arah yang lebih efektif bagi manajemen persekolahan. Menurut Siahaan et al., (2006), Pengawas (supervisor) adalah salah satu tenaga kependidikan, yang bertugas memberikan pengawasan agar tenaga kependidikan (guru, kepala sekolah, personil lainnya di sekolah) dapat menjalankan tugasnya dengan baik. Sudjana (2006) mengemukakan: tenaga pengawas sekolah, (TK/SD, SMP, SMA dan SMK) merupakan tenaga kependidikan yang peranannya sangat penting dalam membina kemampuan profesional tenaga pendidik dan kepala sekolah dalam meningkatkan kinerja sekolah. Pengawas Sekolah merupakan jabatan strategis dalam penyelenggaraan sistem pendidikan nasional yang memiliki tugas pokok menilai dan membina penyelenggaraan pendidikan di sekolah tertentu yang menjadi tanggungjawabnya. Seperti yang dikemukakan Kimball dalam Sahertian (2008) bahwa tugas seorang pengawas adalah untuk membantu, memberi support dan mengajak (Sharing). Berdasarkan pengertian di atas, dapat disimpulkan bahwa pengawas merupakan salah satu komponen yang memiliki peranan penting dalam peningkatan mutu pendidikan. Menurut Siahaan et al., (2006), Kinerja pengawas, walaupun adakalanya bersifat teknis, tetapi memiliki kedudukan yang strategis dalam menciptakan situasi yang kondusif bagi pencapaian kinerja setiap elemen yang ada disekolah, baik itu kepala sekolah, guru, tenaga administrasi, peserta didik dan lainnya yang terlibat secara langsung terhadap proses pembelajaran. Akhir dari pelaksanaan kinerja pengawas adalah terciptanya personil sekolah yang dapat melaksanakan tugas sebagaimana tuntutan kinerjanya, sehingga tercipta situasi yang kondusif untuk melakukan perubahan menuju ke arah yang lebih efektif bagi manajemen persekolahan. Hal ini jika diadakan supervisi, pengawasan dan pem lebihintensif dari Pengawas sekolah tidak mustahil 
akan semakin meningkatkan kemampuan profesional kepala sekolah. Hal itulah yang membuat penelititertarik untuk mengungkap lebih dalam tentang supervisi manajerial pengawas sekolah terhadap peningkatan kemampuan profesional kepala sekolah.

Penelitian tentang Supervisi Manajerial yang dilakukan para Pengawas sekolah diharapkan mampu memberikan kontribusi yang maksimal terhadap peningkatan mutu profesional Kepala Sekolah khususnya di SMA/SMK peneliti di Kabupaten Boalemo yang pada gilirannya berimplikasi terhadap peningkatan mutu Pendidikan Nasional untuk mencerdaskan kehidupan bangsa. Dari penjelasan di atas, maka peneliti sebagai pengawas sekolah SMA/SMK di Wilayah Kabupaten Boalemo merasa bertanggung jawab untuk memperbaiki kendala-kendala yang terdapat di lapangan khususnya yang berkaitan dengan masalah peningkatan profesionalisme guru melalui pem kompetensi pedagogik guru terutama guru kontrak produktif. Perwujudan tindakan yang peneliti lakukan adalah dengan melaksanakan kegiatan penelitian tindakan sekolah dengan judul "Upaya Pengawas untuk meningkatkan kompetensi manajerial kepala sekolah dalam meningkatkan kompetensi pedagogik guru kontrak produktif melalui implementasi program induksi guru pemula dengan teknik individual di SMKN 2 Wonosari Kabupaten Boalemo Provinsi Gorontalo.”

\section{METODE PENELITIAN}

\section{Jenis Penelitian}

Penelitian yang dilakukan merupakan penelitian tindakan kepengawasan Sekolah dalam upaya meningkatkan kemampuan kepala sekolah dalam membimbing guru pemula kearah guru yang professional. Pendekatan yang digunakan dalam penelitian ini adalah pendekatan deskriptif. Apabila datanya telah terkumpul lalu diklasifikasikan menjadi dua kelompok data, yaitu kuantitatif yang berbentuk angka-angka dan data kualitatif yang dinyatakan dalam kata-kata atau simbol. Data kualitatif yang berbentuk kata-kata tersebut disisihkan untuk sementara, karena akan sangat berguna untuk menyertai dan melengkapi gambaran yang diperoleh dari analisis data kuantitatif (Arikunto, 2006). Sehingga dalam penelitian ini diperlukan dulu data kuantitatif yang berbentuk angka, setelah itu baru diperjelas dengan kata-kata.

\section{Waktu dan Tempat Penelitian}

Penelitian ini dilakukan selama 4 (empat) bulan yaitu dari bulan Agustus s.d. bulan Nopember 2016. Tempat penelitiannya di SMKN 2 Wonosari Kabupaten Boalemo.

\section{Target/Subjek Penelitian}

Penelitian ini dilakukan di SMKN 2 Wonosari dengan sasaran Kepala SMKN 2 Wonosari Kabupaten Boalemo sebagai subyeknya. Variabel utama yang digunakan untuk pengukuran adalah sistem manajerial kepala sekolah, kompetensi guru kontrak produktif dan hasil belajar siswa. Sedangkan untuk variabel moderator adalah kompetensi Pedagogik dengan menggunakan kepala sekolah dan guru sebagai media penelitian. Variabel utama yang digunakan untuk pengukuran adalah sistem manajerial kepala sekolah, kompetensi guru kontrak produktif dan hasil belajar siswa. Sedangkan untuk variabel moderator adalah kompetensi Pedagogik .

\section{Teknik Pengumpulan Data \\ Teknik pengumpulan}

Data ini diperoleh dari hasil observasi, wawancara dan dokumentasi.

a. Observasi dipergunakan untuk mengumpulkan data dan mengetahui kinerja kepala sekolah dalam pem guru pemula.

b. Wawancara dapat dipergunakan untuk mengumpulkan data dan mengetahui kemampuan kepala sekolah dalam membimbing guru pemula.

c. Dokumentasi, dipergunakan mencari data mengenai hal-hal atau variabel yang berupa catatan, transkip, buku, surat kabar, majalah, dan sebagainya yang berkaitan dengan kegiatan penelitian (Arikunto, 2006). Sumber data diperoleh dari hasil pemantauan secara berjenjang (Siklus).

\section{Metode Pengumpulan Data}

a. Instrumen Pengamatan Pembelajaran dan Instrumen Peniaian pembelajaran. Kuesioner merupakan kumpulan daftar pertanyaan secara 
tertulis untuk mendapatkan informasi yang dibutuhkan dari para responden.

b. Wawancara. Wawancara ini dilakukan untuk memperoleh informasi yang tidak didapatkan melalui kuesioner.

c. Dokumentasi. dipergunakan mencari data mengenai hal- hal atau variabel yang berupa catatan, transkip, buku, surat kabar, majalah, dan sebagainya yang berkaitan dengan kegiatan penelitian (Arikunto, 2006).

\section{Prosedur}

Penelitian tindakan sekolah ini merupakan tindakan yang bertujuan untuk meningkatkan kemampuan kepala sekolah dalam penyusunan Program Induksi Guru Pemula. Tindakan yang dilakukan adalah melaksanakan Supervisi
Manajerial dengan teknik individual yang dilaksanakan dalam 2 siklus tindakan. Pendekatan yang digunakan dalam penelitian ini adalah pendekatan deskriptif. Apabila datanya telah terkumpul lalu diklasifikasikan menjadi dua kelompok data, yaitu kuantitatif yang berbentuk angka-angka dan data kualitatif yang dinyatakan dalam kata-kata atau simbol. Data kualitatif yang berbentuk kata-kata tersebut disisihkan untuk sementara, karena akan sangat berguna untuk menyertai dan melengkapi gambaran yang diperoleh dari analisis data kuantitatif (Arikunto, 2006). Sehingga dalam penelitian ini diperlukan dulu data kuantitatif yang berbentuk angka, setelah itu baru diperjelas dengan kata-kata. Prosedur penelitiannya menggunakan siklus yang terdiri dari beberapa langkah dengan ketentuan sebagai berikut.

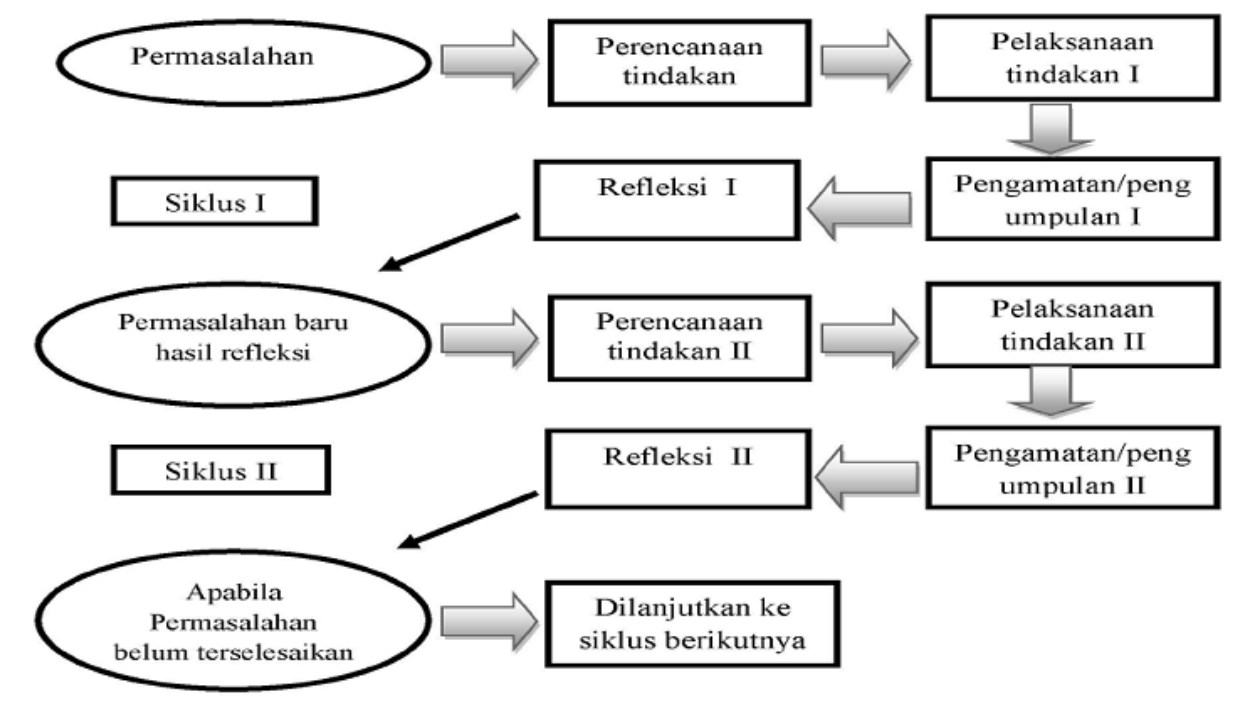

Gambar 1. Siklus dalam Penelitian Tindakan Sekolah

\section{Data, Intrumen, dan Teknik Pengumpulan Data}

Data dapat dieroleh dengan menggunakan teknik Observasi, Wawancara dan Dokumentasi, data dikumpulkan menggunakan instrumen berupa lembar observasi untuk mengetahui peningkatan kemampuan kepala sekolah dalam membimbing guru pemula, pedoman wawancara untuk mengetahui peningkatan kemampuan kepala sekolah dalam membimbing guru pemula, dan dokumentasi, dipergunakan mencari data mengenai hal- hal atau variabel yang berupa catatan, transkip, buku, surat kabar, majalah, dan sebagainya yang berkaitan dengan kegiatan penelitian (Arikunto, 2006).

\section{Teknik Analisis Data}

Analisis data dalam penelitian ini dilakukan secara deskriptif, yaitu mengklasifikasikan data menjadi dua kelompok yaitu data kualitatif dan kuantitatif. Data kualitatif dinyatakan dalam bentuk kata-kata atau simbol sedangkan data kuantitatif adalah data yang berbentuk angka (Arikunto, 2006). Data kualitatif di dapat dengan cara reduksi data yaitu proses penyerdehanaan yang dilakukan melalui seleksi data, pemfokusan dan 
pengabstrakan data mentah menjadi informasi yang bermakna. Paparan data adalah proses pengambilan intisari dari sajian data yang terorganisir dalam bentuk pernyataan kalimat formula yang singkat dan padat tetapi mengandung pengertian luas.

Dalam melakukan analisis data, semua catatan dijadikan landasan berpijak. Isi catatan diperoleh dari hasil observasi. serta hasil pengamatan menggambarkan peningkatan kemampuan kepala sekolah dalam penyusunan program pembinaan guru pemula sebelum diberi tindakan dan sesudah diberi tindakan. Penentuan kualifikasi hasil pembinaan adalah sebagai berikut:

$$
\text { Skor Akhir }=\frac{\text { Jlh Skor Perolehan }}{\text { Skor Maksimal }} \times 100
$$

\begin{tabular}{cccc}
\hline No & Rentang Nilai & Kriteria Nilai & Ket \\
\hline 1 & $91-100$ & Amat Baik & Tuntas \\
2 & $76-90$ & Baik & Tuntas \\
3 & $61-75$ & Cukup & Belum Tuntas \\
4 & $51-60$ & Sedang & Belum Tuntas \\
5 & $<50$ & Kurang & Belum Tuntas \\
\hline
\end{tabular}

\section{HASIL DAN PEMBAHASAN}

Dari data-data yang diperoleh peneliti pada pelaksanaan penelitian tindakan sekolah dengan kegiatan Supervisi Manajerial dengan teknik individual terhadap peningkatan kemampuan kepala Sekolah SMKN 2 Wonosari yaitu: 1. Perencanaan untuk meningkatkan kompetensi Guru Kontrak Produktif di SMKN 2 Wonosari. Perencanaan guru disusun pada awal tahun pelajaran merujuk pasal 4 Kompetensi Guru. 2. Pengembangan Kompetensi Pedagogik guru kontrak produktif di SMKN 2 Wonosari. a. Implementasi Program Induksi Guru Pemula
(PIGP). b. mengikutsertakan guru dalam forum ilmiah (Pendidikan dan latihan) workshop, dan seminar) c. Penyediaan Fasilitas Penunjang d. Studi Lanjut e. Memberikan tunjangan/bonus pada guru yang berprestasi dan guru yang paling professional, f. MGMP Sekolah. 3. Evaluasi peningkatan kompetensi Guru di SMKN 2 Wonosari. a. Dalam meningkatkan kompetensi guru kontrak produktif, Kepala SMKN 2 Wonosari mengadakan evaluasi terhadap perkembangan guru. Evaluasi yang dilakukan adalah dengan melakukan supervisi pendidikan terhadap para guru. b. Teknik supervisi yang digunakan ada tiga yaitu: 1) Teknik kunjungan kelas 2) Pembicaraan pribadi 3) Diskusi kelompok c. Sasaran maupun aspek yang dievaluasi antara lain adalah kehadiran guru dikelas, kinerja guru, prestasi dan perkembangan siswa, catatan kelas dalam hal ini adalah hasil tes siswa, silabus dan RPP guru, media dan metode yang digunakan guru. d. Apabila terdapat guru yang memiliki kendala secara pribadi kepala sekolah membicarakan secara pribadi masalah apa yang sedang dihadapi guru tersebut, kemudian dicarikan solusinya. Dari datadata yang diperoleh peneliti pada pelaksanaan penelitian tindakan sekolah dengan kegiatan Supervisi Manajerial dengan teknik individual terhadap peningkatan kemampuan kepala Sekolah dalam penyusunan Program Induksi Guru Pemula yang terstandar, yaitu: a. kemampuan kepala Sekolah dalam penyusunan standar penyusunan Program Induksi Guru Pemula setelah dilaksanakan Supervisi Manajerial dengan teknik individual, diperoleh rekapitulasi data-data yang berkaitan dengan peningkatan kemampuan kepala Sekolah yang menjadi peneliti terjadi peningkatan pada setiap siklus.

Tabel 1. Rekapitulasi Hasil Pelaksanaan Supervisi Manajerial dengan Teknik Individual Penyusunan Program Induksi Guru Pemula yang Terstandar pada Kondisi Awal, Siklus I, Siklus II

\begin{tabular}{cc|cccccc}
\hline \multirow{2}{*}{ No } & \multirow{2}{*}{ Nama KS } & \multicolumn{3}{|c}{ Awal } & \multicolumn{2}{c}{ Siklus I } & \multicolumn{2}{c}{ Siklus II } \\
\cline { 3 - 8 } & & Nilai & Kriteria & Nilai & Kriteria & Nilai & Kriteria \\
\hline 1 & \multirow{2}{*}{ Supoyo, S.Pd } & 00,00 & Kurang & 70,59 & Cukup & 91,18 & Amat Baik \\
& & 00,00 & Kurang & 72,06 & Cukup & 94,12 & Amat Baik \\
& & 00,00 & Kurang & 75,00 & Cukup & 97,06 & Amat Baik \\
& \multirow{4}{*}{ Jumlah } & 00,00 & - & $\mathbf{2 1 7 , 6 5}$ & - & $\mathbf{2 8 2 . 3 6}$ & - \\
& Rata-Rata & 00,00 & Kurang & $\mathbf{7 2 . 3 3}$ & Cukup & $\mathbf{9 4 , 1 2}$ & Amat Baik \\
\hline
\end{tabular}


Dari tabel 1 dapat dijelaskan peningkatan ketuntasan dari kondisi awal sampai dengan pelaksanaan siklus II sebagaimana tabel 2 dan 3 di bawah ini.

Tabel 2. Rekapitulasi Peningkatan Ketuntasan Hasil Penilaian pada Kondisi Awal, Siklus I, Siklus II

\begin{tabular}{cc|ccc}
\hline & & Awal & Siklus I & Siklus II \\
\hline \multirow{2}{*}{ Tuntas } & Jumlah & 0 & 0 & 0 \\
& $\boldsymbol{\%}$ & 0,00 & 72,33 & 94,12 \\
\hline Belum & Jumlah & 0 & 3 & 0 \\
Tuntas & $\%$ & 100,00 & 27,67 & 5,88 \\
\hline \multicolumn{2}{c}{ Keterangan } & \multicolumn{3}{c}{} \\
\hline
\end{tabular}

Tabel 3. Rekapitulasi Peningkatan Nilai Hasil Penilaian pada Kondisi Awal, Siklus I, Siklus II

\begin{tabular}{cc|ccc}
\hline & & Awal & Siklus I & Siklus II \\
\hline $\begin{array}{c}\text { Perolehan dan } \\
\text { Kriteria Nilai }\end{array}$ & Nilai & 0,00 & 72,33 & 94,12 \\
Keterangan & Kurang & Cukup & Amat Baik \\
\hline \multicolumn{2}{c|}{} & & & \\
\hline
\end{tabular}

\section{Pembahasan}

Berdasarkan hasil observasi peneliti terhadap semua instrumen penyusunan Program Induksi Guru Pemula yang dibuat kepala Sekolah (pada kondisi awal), diperoleh informasi/data bahwa kemampuan kepala Sekolah peneliti dalam penyusunan Program Induksi Guru Pemula masih rendah. Hasil analisis data pada kondisi awal dapat dijelaskan bahwa kemampuan kepala Sekolah masih rendah, hal tersebut dapat dilihat dari perolehan hasil penilaian yang dilakukan peneliti di awal kegiatan penelitian di mana hasil menujukkan nilai dalam kriteria kurang sehingga perlu dilakukan tindakan untuk meningkatkan kemampuan kepala Sekolah dengan menerapkan Supervisi Manajerial dengan teknik individual. Pada pelaksanaan siklus pertama, upaya yang dilakukan peneliti adalah menerapkan kegiatan Supervisi Manajerial dengan teknik individual sebagai upaya meningkatkan kemampuan kepala Sekolah dalam penyusunan Program Induksi Guru Pemula. Pada tahap tindakan, setelah melaksanakan kegiatan awal penelitian, dan guna meningkatkan pemahaman Kepala Sekolah dalam penyusunan Program Induksi Guru Pemula, peneliti bersama-sama dengan kepala sekolah melaksanakan diskusi tentang pelaksanaan penyusunan Program Induksi Guru Pemula yang ideal sesuai dengan petunjuk teknis dan petunjuk pelaksanaan dari instansi berwenang. Dalam pelaksanaan diskusi tersebut di bahas tentang standar baku penyusunan Program Induksi Guru Pemula yang harus dimiliki oleh para Kepala Sekolah. Setelah memberikan penjelasan, kepala Sekolah diminta berdiskusi tentang dokumen-dokumen yang harus ada dalam penyusunan Program Induksi Guru Pemula. Kepala Sekolah diminta membuat beberapa contoh tentang dokumen-dokumen penunjang dengan menggunakan format isian penyusunan penyusunan Program Induksi Guru Pemula yang terdiri dari 7 indikator dan 17 sub indikator. Hasil analisis data hasil penelitian kondisi awal, kepala Sekolah dinyatakan kurang kemampuannya dalam menyusun Program Induksi Guru Pemula karena dalam penilaian di mana pada kondisi awal kepala Sekolah tidak mampu menyusun Program Induksi Guru Pemula, dengan baik, dalam arti perolehan nilai $(0 \%)$ atau dengan kriteria kurang. Pada siklus I meningkat nilai menjadi $72,33 \%$ dengan kriteria cukup, dan pada siklus terakhir (Sikluis II) nilai 94,12 dengan kriteria Amat Baik. Berdasarkan pada hasil peroleh data yang ditunjukkan dengan hasil penilaiannya, maka kegiatan penelitian ini diakhiri karena sudah memenuhi target yang diharapkan. Namun untuk pengembangannya masih terdapat 5,88\% yang masih perlu disempurnakan hungga benar-benar tuntas menjadi 100\%. Dari hasil analisis data tersebut masih terdapat beberapa hal yang perlu mendapatkan perhatian. Adapun hal-hal yang masih perlu mendapat perhatian antara lain adalah: Pada siklus 1, 1. Pada program Kegiatan pengembangan Kurikulum yaitu Guru Pemula belum mengembangkan materi pembelajaran yang sesuai, 2. Pada aktivitas pengembangan pendidikan, Guru Pemula belum mengembangkan dan menggunakan media pembelajaran yang tepat, 3 . 
Pada Penilaian dan evaluasi, Guru Pemula belum mengevaluasi efektifitas program dan proses pembelajaran serta belum pula menggunakan hasil penilaian dan evaluasi untuk perencanaan dan pembelajaran selanjutnya, 4. Secara umum kepala Sekolah belum mampu mengkoordinasikan dengan baik seluruh tim penyusun di sekolahnya sehingga masih terdapat permasalahan dan kendala-kendala dalam penyusunan Program Induksi Guru Pemula, 5. Ketidaksempurnaan kepala Sekolah dalam menyusun Program Induksi Guru Pemula dapat diatasi dengan memberikan penjelasan dan unjuk kerja tentang cara penyusunan Program Induksi Guru Pemula sesuai dengan standar yang baku pada buku Panduan Kerja Program Induksi Guru Pemula yang diterbitkan oleh Instansi yang berwenang. Pada siklus 2, Dimulai dengan kegiatan mengumpulkan tim penyusun dan kepala Sekolah pada salah satu ruangan. Pada tahap tindakan ini, peneliti melaksanakan kegiatan diskusi membahas tentang standar baku penyusunan Program Induksi Guru Pemula, di mana sebelumnya peneliti telah menjelaskan tentang standar Program Induksi Guru Pemula yang baku dengan menggunakan power point melalui media LCD. Setelah cukup memberikan penjelasan dengan menggunakan presentasi powerpoint, kepala Sekolah diminta berdiskusi tentang dokumen-dokumen yang harus ada dalam penyusunan Program Induksi Guru Pemula. Kepala Sekolah diminta membuat beberapa contoh tentang dokumen-dokumen penyusunan Program Induksi Guru Pemula. Kegiatan ini dimaksudkan agar kepala Sekolah semakin mengerti dan paham tentang standar penyusunan Program Induksi Guru Pemula, serta mencari tahu secara mandiri kekurangankekurangan apa yang dimiliki oleh kepala Sekolah dalam penyusunan Program Induksi Guru Pemula. Berdasarkan analisi data hasil penelitian pada siklus II, nampak kepala Sekolah peneliti sudah memahami dengan baik tentang standar penyusunan Program Induksi Guru Pemula dengan baik. Hal tersebut nampak dari kesiapan para kepala Sekolah untuk mempersiapkan format isian penyusunan standar biaya pendidikan. Dari hasil siklus II dapat simpulkan bahwa pada dasarnya kemampuan kepala Sekolah dalam penyusunan Program Induksi Guru Pemula yang terstandar telah memenuhi kriteria keberhasilan. Setelah memperhatikan seluruh rangkaian pelaksanaan tindakan pada siklus II, dapat disimpulkan bahwa: 1. Kepala Sekolah sudah mampu penyusunan Program Induksi Guru Pemula dengan baik dilihat dari kinerja indivual kepala Sekolah yang sudah mampu dalam berkoodinasi dengan tim penyusun di sekolahnya. 2. Semua dokumen wajib maupun pendukung telah dibuat oleh kepala Sekolah dengan baik walaupun masih ada beberapa kekurangan tetapi secara keseluruhan kinerja dan kemampuan Kepala Sekolah dalam penyusunan Program Induksi Guru Pemula maupun dalam berkoodinasi dengan tim penyusun di sekolahnya meningkat dengan baik.

\section{SIMPULAN}

Dari data hasil analisis sebagaimana dijelaskan pada bab sebelumnya, mengenai pelaksanaan kegiatan penelitian tindakan kepengawasan yang dilakukan di SMKN 2 Wonosari dapat disimpulkan bahwa: (1) Model pem Kepala Sekolah dalam Penyusunan Program Induksi Guru Pemula melalui Supervisi Manajerial dengan teknik individual di SMKN 2 Wonosari terbukti mampu meningkatkan kemampuan Kepala Sekolah dalam Menyusun Program Induksi Guru Pemula sehingga diperoleh suatu pengalaman baru dalam penyelenggaraan model pem; (2) Dari kondisi awal, siklus I hingga siklus II disimpulkan bahwa telah terjadi peningkatan kemampuan Kepala Sekolah dalam menyusun Program Induksi Guru Pemula. Hasil observasi dan penilaian menunjukkan bahwa terjadi peningkatan kemampuan kepala Sekolah secara signifikan setelah dilaksanakan kegiatan pem dengan supervisi manajerial. Hal tersebut dapat dilihat pada hasil yang diperoleh, yaitu pada kondisi awal kepala Sekolah belum mampu menyusun Program Induksi Guru Pemula, sehingga capaian nilai kinerjanya 0 (0\%), dengan kriteria kurang, pada siklus I meningkat menjadi $72,33 \%$, dengan kriteria cukup, dan pada siklus II menjadi $94,12 \%$ dalam kriteria Amat Baik. Melihat data perolehan hasil penelitian dalam kegiatan penelitian tindakan kepengawasan 
ini, dapat disimpulkan bahwa supervisi manajerial yang dilakukan oleh pengawas sekolah terhadap kepala SMKN 2 Wonosari, dinyatakan berhasil meningkatkan kemampuan kepala Sekolah dalam penyusunan Program Induksi Guru Pemula. Sebagai uji coba kemampuan Program Induksi Guru Pemula, instrumen yang telah dibuat diuji cobakan pada kegiatan pembelajaran guru kontrak produktif di sekolah tersebut dengan hasil yang cukup menggembirakan, yaitu $94,12 \%$ capaian yang diperoleh pada akhir siklus.

\section{UCAPAN TERIMA KASIH}

Dengan selesainya penelitian ini, maka penulis menyampaikan ucapan terima kasih kepada pihak-pihak yang telah membantu keterlaksanaan penelitian ini terutama kepada Kepala Dinas Pendidikan Kabupaten Boalemo yang telah memberi izin penelitian ini, lebih khusus kepada Kepala SMKN 2 Wonosari beserta seluruh staf dewan guru dan tata usaha yang telah memfasilitasi keterlaksanaan kegiatan penelitian sejak dari perencanaan hingga akhir kegiatan.

\section{DAFTAR PUSTAKA}

Arikunto, S. (2006). Prosedur Penelitian Suatu Pendekatan Praktik. Jakarta: Rineka Cipta.

MenegPAN dan RB (2009). PermenegPAN dan RB nomor 16 tahun 2009 tentang jabatan funsional guru dan angka kreditnya. Jakarta.

Sudjana, N. (2006). Penilaian Hasil Proses Belajar Mengajar. Bandung: PT. Remaja Rosdakarya.

Sahertian, P. A. (2008). Konsep Dasar dan Teknik Supervisi Pendidikan Dalam Rangka Pengembangan Sumber Daya Manusia, Jakarta: Rineka Cipta.

Siahaan, A., Asli, R., \& Mahidin. (2006). Manajemen Pengawas Pendidikan. Jakarta: Quatum Teaching Ciputat Press Group. 